\title{
Effects of Reproductive Health Education Using Video Animation Towards Reproductive Health Knowledge and Attitudes in 5th and 6th Elementary Grade Students in Serang City, Banten
}

\author{
Edy Mustofa ${ }^{1}$, I Made Arya Subadiyasa ${ }^{2}$, Agus Sholahuddin ${ }^{3}$, Arif Rahman Nurdianto ${ }^{4}$ \\ Study Program of Social Gynecology Obstetrics Sub-Center Malang ${ }^{1}$ \\ Study Program of Social Gynecology Obstetrics Sub-Center Malang ${ }^{2}$ \\ Study Program of Social Gynecology Obstetrics Sub-Center Malang ${ }^{3}$ \\ Lecture in Magister Immunology Program, Postgraduate School, Universitas Airlangga ${ }^{4}$ \\ *e-mail: edy.mustofa.obgynsos@gmail.com
}

\begin{abstract}
Abstrak
Latar belakang: Edukasi kesehatan reproduksi remaja bertujuan untuk meningkatkan pengetahuan dan sikap tentang kesehatan reproduksi. Oleh karena itu, diperlukan metode edukasi yang mudah, murah, dan terstandarisasi untuk menyampaikan materi kesehatan reproduksi kepada remaja, salah satunya adalah dengan media animasi audiovisual.

Metode: Penelitian ini dilakukan dengan menggunakan desain penelitian pra-eksperimental pretest-posttest one group design pada kelompok studi dalam waktu 31 hari. Studi ini menggunakan total subyek sebanyak 180 subyek, selanjutnya, data dianalisis menggunakan Structural Equation Modeling (SEM).

Hasil: Edukasi dengan video animasi kesehatan reproduksi dapat meningkatkan pengetahuan tentang kesehatan reproduksi segera setelah edukasi diberikan $(P=0,002)$, tetapi setelah 31 hari, pengaruh edukasi tersebut menghilang $(P=0,171)$. Edukasi dengan video animasi tidak mempengaruhi sikap subjek segera setelah edukasi dilakukan $(P=0,802)$ akan tetapi memiliki efek setelah 31 hari sejak awal edukasi diberikan $(P=0,031)$. Setelah menganalisis korelasi termasuk variabel confounding lainnya ( $\mathrm{R}$ square), Ditemukan bahwa efek edukasi dengan video animasi terhadap meningkatnya pengetahuan tentang kesehatan reproduksi adalah sebesar $14,9 \%$, dan $8,4 \%$ terhadap perubahan sikap subjek.

Diskusi: Edukasi kesehatan dengan video animasi dapat meningkatkan pengetahuan, Kemungkinan edukasi ini dapat mengubah pengetahuan melalui rangsangan positif pada dorsolateral prefrontal cortex (DLPFC) dan supplementary motor area (SMA) sehingga dapat dengan cepat diterima oleh otak namun fenomena sikap seperti kencan masih terjadi bahkan pengetahuan subjek telah meningkat.
\end{abstract}

Kesimpulan: Edukasi kesehatan reproduksi menggunakan video animasi meningkatkan pengetahuan tetapi tidak mengubah sikap dalam kesehatan reproduksi

Kata kunci: sikap, pengetahuan, video animasi, kesehatan reproduksi

\begin{abstract}
Introduction: Adolescent reproductive health education aims to increase knowledge and attitudes about reproductive health. Therefore, an easy, inexpensive, and standardized method of education is needed in the delivery of reproductive health material to young adolescents, one of them is audiovisual media animation.
\end{abstract}


Effects of Reproductive Health Education Using Video Animation Towards Reproductive...

Edy Mustofa, I Made Arya Subadiyasa, Agus Sholahuddin, Arif Rahman Nurdianto

Method: The research was conducted using a pre-experimental research design pretest-posttest one group design within 31 days. This study used a total sample of 180 subjects, furthermore, the data were analyzed using Structural Equation Modeling (SEM).

Result: Education with reproductive health animated videos increased knowledge about reproductive health immediately after education was given $(P=0.002)$, but after 31 days, it did not affect $(P=0.171)$. Education with animated videos did not affect the subjects' attitude immediately after education was carried out $(P=0.802)$ but had an effect after 31 days from the start of education $(P=0.031)$. After analyzing the correlation including other confounding variables ( $R$ square), it was found that the effect of education with animated videos towards the increasing knowledge of reproductive health was $14.9 \%$, and $8.4 \%$ towards changes in subject attitudes.

Conclusion: Reproductive health education using animated videos increases knowledge but does not change attitudes in reproductive health

Keywords: attitude, knowledge, video animation, reproductive health

\section{INTRODUCTION}

Puberty is marked by various changes, both biological, psychological, and social. These changes can cause problems including reproductive health issues (BKKBN, 2013; Nurdianto, 2020; Bolin, 2009). According to the 2012 Indonesia Demographic Health Survey (SDKI), the knowledge of adolescent in Indonesia related to reproductive health is considered to be lacking (Sholiha, 2015) On the other hand, the majority of Indonesian people, especially parents are still reluctant and even consider taboo to discuss about developments and issues related to reproductive health and puberty with their children (Hull et al, 2005; Kemenkes RI, 2017; Kusmiran; 2011; Maharani et al, 2016)

Knowledge about adolescent reproductive health is affected by many things, including the ease of accessing mass media, television, and the internet that can have either positive or negative impact on adolescent knowledge related to reproductive health (Catarina, 2011; Christie et al, 2005; Depkes RI, 2000). The knowledge possessed by adolescents will affect sexual attitudes and behavior, especially during puberty (Manuaba, 1998; Murre et al, 2015; Notoatmodjo, 2012, 2013; Prijati et al., 2016).

As the result, proper and comprehensive knowledge of reproductive health is needed. The knowledge is obtained through various means, one of them is education (Purwanto, 2000; Samandari et al., 2010; Santhya et al., 2010). Adolescent reproductive health education aims to increase adolescent knowledge that affects attitudes and ablility to lead to adolescent motivation to learn more about reproductive health through appropriate educational methods (Astri et 
al., 2016; Ahmadi, 2009; Poltekkes Depkes Jakarta, 2012).

Based on the information above, the researchers try to find easy, inexpensive, non-vulgar, and standardized methods in the delivery of reproductive health material, one of them is using video animation (Poltekkes Depkes Jakarta, 2012).

\section{METHOD}

This type of research is a quantitative study with a pre-experimental research design pretest - posttest one group design (Sofyani, 2015) The research data was taken from January 2019 to February 2019. The study was located in three locations, those are Sekolah Dasar Negeri (SDN) Sawah Luhur, Sekolah Dasar (SD) Lopang Domba, and SDN Terondol, Serang City Banten. The subjects were all elementary school students grade 5 and 6 who were present during the pretest, education, and post-test and 31 days after the post-test. The pretest is given to subjects to find out the extent of their knowledge and attitudes about reproductive health. After that, they were given education on reproductive health using video animation and then given a post-test. After that, the researcher will give a post-test again 31 days afterward to measure whether the material provided can be obtained properly in a long time or not (Sofyani, 2015)

Sampling used in this research is a total sampling technique of 180 subjects. The data is analyzed using Structural Equation Modeling (SEM) and continued with correlation analysis including the other confounding variables (R square). This study has obtained ethical clearance from the Health Research Ethics Moment of Rumah Sakit Umum Daerah (RSUD) Saiful Anwar Malang (No. 400/207/K.3/302/2019).

\section{RESULTS}

A total of 187 subjects participated in the questionnaire sampling, but 7 of them did not complete the questionnaire, therefore, it could not be analyzed. Respondents who were the subjects of the study were 180 students (Table 1).

According to the results of the questionnaire (Table 2), $44.7 \%$ of male students had shown a primary sign of puberty which was having a wet dream where spermarche usually occurs at an average age of 13.4 years (WHO, 2011), while $40 \%$ of students women already menstruate where menarche generally occurs on average 12.8 years of age (Wiknjosastro, 2007)

It was found that $39.4 \%$ of the subjects admitted that they had been dating and $50 \%$ of the student subjects had started 
Effects of Reproductive Health Education Using Video Animation Towards Reproductive... Edy Mustofa, I Made Arya Subadiyasa, Agus Sholahuddin, Arif Rahman Nurdianto

to be attracted to the opposite sex. This case should receive special attention. Exposure to good and comprehensive information and the social environment or peers have an important role in providing a positive and protective effect on adolescent reproductive health.

Before testing the hypothesis, the measurement model is evaluated first for verifying indicators and latent variables. In the reliability indicator, a reflective indicator must be eliminated from the research model when the loading value is $<0.4$. Then the questions from the knowledge questionnaire including $\mathrm{P} 1, \mathrm{P} 7$, $\mathrm{P} 8, \mathrm{P} 11, \mathrm{P} 12, \mathrm{P} 14, \mathrm{P} 15$, as well as from the attitude questionnaire including S4, S7, S8, S10 were eliminated because they were considered invalid and reliable.

Questionnaires analyzed for knowledge were P2, P3, P4, P5, P6, P9, P10, and P13 and for attitudes were S1, S2, S3, S5, S6, and S9 (Table 3).

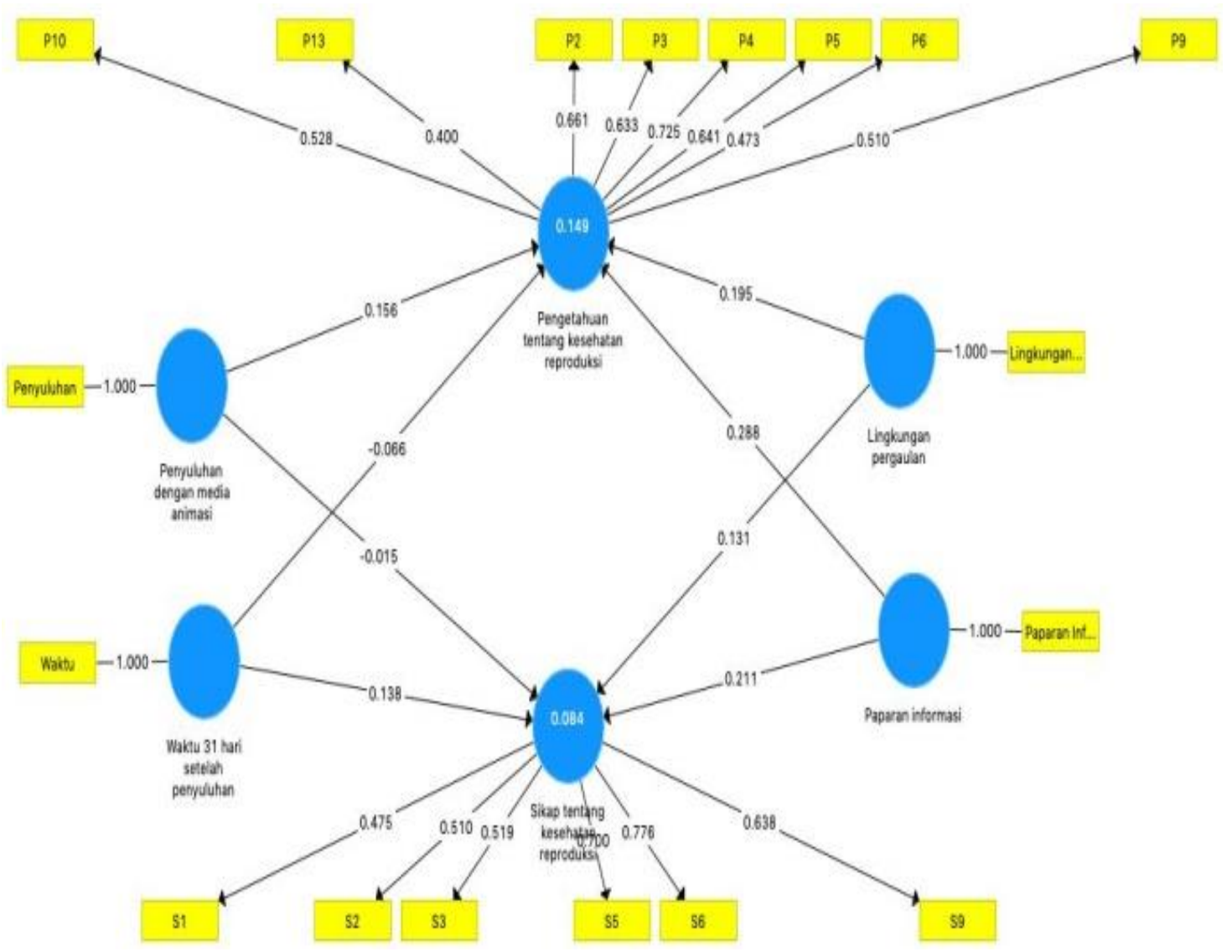

Figure 1. Final Path Chart included with Factor Loading Values after Elimination of Phase 2 Indicators 
Table 1 History of Menstruation in Female Students and Wet Dreams in Male Students

\begin{tabular}{lccc}
\hline & Already & Not Yet & Total \\
\hline Already got wet dream & 38 & 47 & 85 male student \\
Already got menstruation & 38 & 57 & 95 female student \\
\hline
\end{tabular}

Table 2. History of dating and being attracted to the opposite sex

\begin{tabular}{lccc}
\hline & Yes & No & Total \\
\hline Dating history & 71 & 109 & 180 \\
Being attracted to the opposite sex & 90 & 90 & 180 \\
\hline
\end{tabular}

Table 3. Correlations between Variables

\begin{tabular}{lcc}
\hline & $\begin{array}{c}\text { Knowledge of reproductive } \\
\text { health }\end{array}$ & $\begin{array}{c}\text { Attitudes about } \\
\text { reproductive health }\end{array}$ \\
\hline Social environment & 0,195 & 0,131 \\
Information exposure & 0,288 & 0,211 \\
Education with video animation (pre test) & 0,156 & $-0,015$ \\
31 days after education (posttest) & $-0,066$ & 0,138 \\
\hline
\end{tabular}

Table 4. Calculation Results Using Bootstrapping

\begin{tabular}{lccc}
\hline & Standard Deviation & T Statistics & P Values \\
\hline Social environment $\rightarrow$ Knowledge & 0,044 & 4,451 & 0,000 \\
Social environment $\rightarrow$ Attitude & 0,062 & 2,109 & 0,035 \\
Information exposure $\rightarrow$ Knowledge & 0,037 & 7,724 & 0,000 \\
Information exposure $\rightarrow$ Attitude & 0,045 & 4,716 & 0,000 \\
Education $\rightarrow$ Knowledge & 0,049 & 3,157 & 0,002 \\
Education $\rightarrow$ Attitude & 0,061 & 0,251 & 0,802 \\
31 days $\rightarrow$ Knowledge & 0,048 & 1,372 & 0,171 \\
Time 31 days $\rightarrow$ Attitude & 0,064 & 2,168 & 0,031 \\
\hline
\end{tabular}

\section{DISCUSSION}

The hypothesis of reproductive health education using animated videos can improve knowledge of reproductive health is proven to be $P=0.002(P<0.05)$, but after 31 days of education, it does not affect $(P=$ $0.171)$.

These results are in line with research conducted by Benita (2012), Buzarudina (2013), Astri (2016), and Johariyah (2018) which concluded that reproductive health education using various methods will affect reproductive health knowledge. Animated videos in this study can increase knowledge in subjects (Johariah et al, 2018; Benita, 2012; Bensley et al., 2008; Buzarudina et al., 2013). The level of knowledge after 31 days post-education in this study is not statistically significant, which might due to education through animated videos is not repeated (kardes, 2001).

The results showed that $39.4 \%$ of the subjects were dating and $50 \%$ began to be attracted to the opposite sex. These results can be inferred that it was obtained from the influence of film, television, social media, and the environment around the subject that causes the subject to feel interested in imitating the dating behavior 
Effects of Reproductive Health Education Using Video Animation Towards Reproductive...

Edy Mustofa, I Made Arya Subadiyasa, Agus Sholahuddin, Arif Rahman Nurdianto

of their idol actor or actress in all of those media. This is in line with the results of a survey by the Indonesian Family Planning Association (PKBI) in Central Java, which shows that around $40 \%$ of the subjects admitted to having been dating and $73.3 \%$ of them started dating from the age of 10 15. Among adolescents who have been dating, $11.2 \%$ of them admitted that they had handled their partner's reproductive organs (Sukmaningsih et al., 2018) These cases make this animated video education very necessary to change dating habits and attraction between the opposite sex from an early age.

The hypothesis of reproductive health education using animated videos has an effect on attitudes about reproductive health was not proven in this study, which was indicated by a value of $P=0.802(P>$ 0.05). Interestingly, after 31 days, education with animated videos affects attitudes about reproductive health $(P=0.031)$. The possibility of this happens because there are other factors within 31 days after an education that affect attitudes about reproductive health, such as increased awareness of adolescents about reproductive health which then affects the attitude of the subject. After all, one's attitude is strongly influenced by the formation of perceptions of reproductive health attitudes after 31 days of education, where the process of forming the subject's perception starts from a stimulus received by the senses, in this case, is categorized as audio-visual stimulation (Damayanti, 2000) The stimuli are then selected and run into an organizing process. After that, the individual will assess or interpret the data that has been received, thus a person's perception is formed (Damayanti, 2000) The occurrence of perception is influenced by internal and external factors. Internal factors include feelings, attitudes, and individual personalities, prejudice, desires, attention, physical conditions, mental disorders, needs, and motivation. External factors include family background, information obtained, knowledge, intensity, size, opposites, repetition of motion, and new things (Ardiyanti et al, 2013; Arisana et al., 2012). All of these things are thought to affect changes in the reproductive health attitudes of subjects after receiving education through animated videos.

\section{CONCLUSION}

Reproductive health education using animated videos increases knowledge but does not change attitudes in reproductive health. The phenomenon of dating at an early age is one of the findings that can be developed into new research, therefore adolescents do not experience reproductive health problems later in life. 


\section{ACKNOWLEDGEMENTS}

The authors would like to express gratitude for the Study Program of Social Gynecology Obstetrics Sub-Center Malang, Universitas Brawijaya which was willing to help with this research.

\section{DISCLOSURE}

The author reports no conflicts of interest in this Research entitled Effects of Reproductive Health Education Using Animation Media on Knowledge and Attitudes about Reproductive Health in Elementary and 5th Grade Students in Serang City, Banten.

\section{ABBREVIATIONS}

Indonesia Demographic Health

Survey (SDKI); Sekolah dasar negeri (SDN);

Sekolah dasar (SD); Structural Equation

Modeling (SEM); Rumah Sakit Umum

Daerah (RSUD)

\section{REFERENCES}

Ahmadi, 2009. Psikologi Umum. rev.ed. PT Rineka Cipta. Jakarta.

Ardiyanti M, and Muti'ah T, 2013. Hubungan Antara Pengetahuan Kesehatan Reproduksi dengan Perilaku Seksual Remaja SMA Negeri 1 Imogiri. Jurnal Spirits, Vol 3, 1-14.
Arisana A and Ismani, 2012. Pengaruh Kedisiplinan Siswa dan Persepsi tentang Kualitas Mengajar Guru Tehadap Prestasi Belajar Akuntasi Siswa Kelas XI IPS MAN Yogyakarta 2 Tahun Ajaran 2011/2012. Jurnal Pendidikan Akuntansi Indonesia. 10: $22-42$.

Astri LA, Winarni S, Dharmawan Y, 2016. Pengaruh Pemberian Pendidikan Kesehatan Reproduksi Terhadap Tingkat Pengetahuan Remaja Awal Sekolah Dasar di Daerah Wisata Bandungan, Kabupaten Semarang Tahun 2016. Jurnal Kesehatan Masyarakat. 4 (4): 213 219.

Benita NR, 2012. Pengaruh Penyuluhan Terhadap Tingkat Pengetahuan Kesehatan Reproduksi Pada Remaja Siswa SMP Kristen Gergaji. Laporan Hasil Karya Tulis IImiah. Program Pendidikan Sarjana Kedokteran Fakultas Kedokteran Universitas Diponegoro.

Bensley RJ, Brookins-Fisher J, 2008. Metode pendidikan kesehatan masyarakat. Jakarta: EGC

BKKBN, BPS, Kementrian kesehatan, MEASURE DHS ICF International 2013. Survei Demografi dan Kesehatan Indonesia 2012. Kesehatan Reproduksi Remaja. 
Effects of Reproductive Health Education Using Video Animation Towards Reproductive...

Edy Mustofa, I Made Arya Subadiyasa, Agus Sholahuddin, Arif Rahman Nurdianto

Bolin A, Whelehan P, 2009. Human sexuality:

biological,

psychological, and cultural perspectives. Routledge. New York.

Buzarudina F, Fitriangga A, Putri EA, 2013.

Efektivitas Penyuluhan Kesehatan Reproduksi Remaja Terhadap Tingkat Pengetahuan Siswa SMAN

6 Kecamatan Pontianak Timur Tahun 2013. Naskah Publikasi. Program Studi Pendidikan Dokter Fakultas Kedokteran Universitas Tanjungpura.

Catarina Y, 2011. Pengaruh pemberian pamflet persalinan terhadap tingkat pengetahuan dan tingkat kecemasan ibu hamil. Skripsi. Universitas Diponegoro. Semarang.

Christie D, Viner $R$, 2005. $A B C$ of adolescence. Adolescent development. BMJ (330): 301 304.

Damayanti R, 2000. Dasar-Dasar Psikologi. Jakarta: FKM UI.

Departemen Kesehatan Republik Indonesia. 2000. Modul pelatihan bimbingan dan penyuluhan kesehatan reproduksi remaja bagi petugas kesehatan: pegangan bagi pelatih. Depkes RI. Jakarta.
Hindin MJ, Fatusi AO, 2009 Adolescent sexual and reproductive health in developing countries: an overview of trends and interventions. Int Perspect Sex Reprod Health. 35(2):58-62.

Hull TH, Hasmi E, Widyantoro N, 2005. Peer educator initiatives for adolescent reproductive health projects in Indonesia. Reprod Health Matters. 12(23):29-39.

Johariah A, Mariati T, 2018. Efektivitas Penyuluhan Kesehatan Reproduksi Remaja Dengan Pemberian Modul Terhadap Perubahan Pengetahuan Remaja. Jurnal manajemen Kesehatan Yayasan RS Dr Soetomo. 4(1).

Kardes, Frank R, 2001. Consumer Behavior, New York: Mac Millan Publishing Company.

Kementerian Kesehatan Republik Indonesia. 2017. Profil Kesehatan Indonesia 2016. Kementerian Kesehatan R.I. Jakarta.

Kusmiran E, 2011. Kesehatan reproduksi remaja dan wanita. Salemba Medika. Jakarta.

Maharani SM, Riyadi A, Wardani AL, 2016. Media Penyuluhan Kesehatan Reproduksi Berbasis Animasi Dan Multimedia Pada Remaja Di Badan Kependudukan Keluarga 
Berencana Nasional (BKKBN).

Skripsi. Program Studi Teknik

Informatika Fakultas Teknik

Universitas PGRI Yogyakarta.

Manuaba, 1998. Memahami Kesehatan

Reproduksi Wanita. EGC. Jakarta.

Nurdianto, Arif Rahman, 2020. Zero

Maternal Death with KECUBUNG

Featured in SATE Krembung

Application (Integrated Queue

System) in Krembung Community

Health Center from 2017 until

2018. Qanun Medika. 4 (1): 59-67.

Murre JMJ, Dros J, 2015. Replication and Analysis of Ebbinghaus' Forgetting Curve. PLOS ONE 10(7).

Notoatmodjo S, 2013. Pendidikan dan perilaku kesehatan. PT Rineka Cipta. Jakarta.

Notoatmodjo S, 2012. Promosi Kesehatan dan Ilmu Perilaku. PT Rineka Cipta. Jakarta.

Poltekkes Depkes Jakarta I, 2012. Kesehatan remaja: problem dan solusinya. Salemba Medika. Jakarta.

Prijatni I, Rahayu S, 2016. Kesehatan Reproduksi dan Keluarga Berencana, Modul bahan ajar cetak kebidanan. Kementrian Kesehatan Republik Indonesia.

Purwanto E, 2000. Perbandingan tingkat pengetahuan kesehatan reproduksi siswa sekolah menengah umum di pedesaan dan perkotaan. Tesis. Universitas Diponegoro. Semarang

Samandari G, Speizer IS, 2010. Adolescent sexual behavior and reproductive outcomes in Central America: trends over the past two decades. Int Perspect Sex Reprod Health. 36(1):26-35.

Santhya KG, Ram U, Acharya R, Jejeebhoy SJ, Ram F, Singh A, 2010. Associations between early marriage and young women's marital and reproductive health outcomes: evidence from India. Int Perspect Sex Reprod Health. 36(3):132-139.

Sholiha EUN, Salamah M, 2015. Structural Equation Modeling-Partial Least Square Untuk Pemodelan Derajat Kesehatan Kabupaten/Kota di Jawa Timur (Studi Kasus Data Indeks Pembangunan Kesehatan Masyarakat Jawa Timur 2013). Jurnal Sains dan Seni ITS. 4(2).

Sofyani H, 2015. Modul Praktis Partial Least Square (PLS) Untuk Penelitian Akuntansi Pendekatan Kuantitatif. Prodi Akuntansi. Universitas Muhammadiyah Yogyakarta.

Sukmaningsih W, Nugraheni S, and Kartini A, 2018. Pengaruh Film Pendek melalui Peer Educator terhadap 
Effects of Reproductive Health Education Using Video Animation Towards Reproductive...

Edy Mustofa, I Made Arya Subadiyasa, Agus Sholahuddin, Arif Rahman Nurdianto

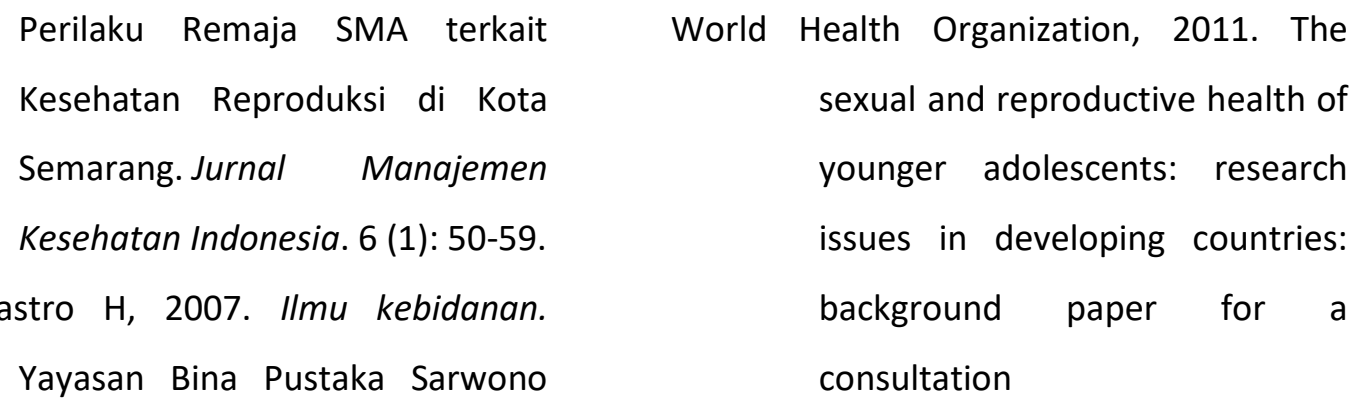

Prawirodihardjo. Jakarta. 